\title{
MASTER
}

DOE/ET/27202-2

\section{SHALE RECHARGE AND PRODUCTION BEHAVIOR OF GEOPRESSURED RESERVOIRS}

TOPICAL REPORT

s. $K_{1}$ GARG

APRIL 1980

WORK PERFORMED UNDER CONTRACT

DE-AC-08-79ET27202

SYSTEMS, SCIENCE AND SOFTWARE

$$
\begin{gathered}
\text { P. O. Box } 1620 \\
\text { LA JOLLA, CA } 92038
\end{gathered}
$$

\author{
PREPARED FOR \\ DEPARTMENT OF ENERGY \\ Nevada Operations OfFICE
}




\section{DISCLAIMER}

This report was prepared as an account of work sponsored by an agency of the United States Government. Neither the United States Government nor any agency Thereof, nor any of their employees, makes any warranty, express or implied, or assumes any legal liability or responsibility for the accuracy, completeness, or usefulness of any information, apparatus, product, or process disclosed, or represents that its use would not infringe privately owned rights. Reference herein to any specific commercial product, process, or service by trade name, trademark, manufacturer, or otherwise does not necessarily constitute or imply its endorsement, recommendation, or favoring by the United States Government or any agency thereof. The views and opinions of authors expressed herein do not necessarily state or reflect those of the United States Government or any agency thereof. 


\section{DISCLAIMER}

Portions of this document may be illegible in electronic image products. Images are produced from the best available original document. 


\section{DISCLAIMER}

This report was prepared as an account of work sponsored by the United States Government. Neither the United States nor the United States Department of Energy, nor any of their employees, makes any warranty, express or implied, or assumes any legal liability or responsibility for the accuracy, completeness, or usefulness of any information, apparatus, product, or process disclosed, or represents that its use would not infringe privately owned rights. Reference herein to any specific commerical product, process, or service by trade name, mark, manufacturer, or otherwise, does not necessarily constitute or imply its endorsement, recommendation, or favoring by the United States Government or any agency thereof. The views ano opinions of authors expressed herein do not necessarily state or reflect those of the United States Government or any agency thereof.

Printed in the United States of America

Available from:

National Technical Information Service

U. S. Department of Commerce

528 s Port Royal Road

Springfield, Virginia 22161

Price:

Printed Copy

$\$ 5.00$

Microfiche

$\propto 3.50$ 


\section{DOE/ET/27202-2 \\ Distribution Category - UC-66A}

\section{SHALE RECHARGE AND PRODUCTION BEHAVIOR OF GEOPRESSURED RESERVOIRS}

TOPICAL REPORT

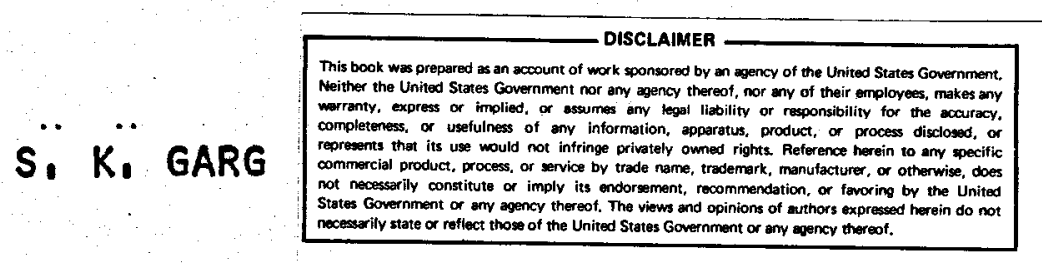

APRIL 1980
$\checkmark$ SYSTEMS, SCIENCE AND SOFTWARE
P, O, BOX 1620
LA JOLLA, CA 92038

PREPARED FOR THE

U. S. DEPARTMENT OF ENERGY

UINDER CONTRACT DE-AC-08-79ET27202 
SSS-R-80-4453

\section{TABLE OF CONTENTS}

SECTION

PAGE

ABSTRACT ......................... . . i

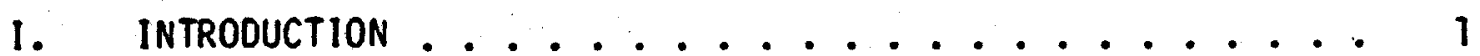

11. NUMERICAL CALCULATIONS .......................... 4

111. SUMmarY AND CONClusions ................ 17

REFERENCES ........................ 18 


\section{ABSTRACT}

The reservoir simulator MUSHRM was used to study the conditions under which significant shale recharge may be expected. The calculations presented herein show that shale recharge is a strong function of the vertical shale permeability but is not greatiy influenced by the shale compressibility. Significant shale recharge will occur only if the vertical shale permeability is at least of the order of $0.01 \mu d$. 


\section{INTRODUCTION}

Wallace, et al: [1] have recently estimated the accessible volume of water stored in the geopressured sandstone and shale beds of the northern Gulf of Mexico basin. Approximately 10 percent of this volume occurs in sandstone, and about 90 percent occurs in shale. On the basis of sandstone percentage, three generalized depositional facies can be identified in the Gulf basin:

1. A massive sandstone facies in which sandstone constitutes at least 50 percent of the total volume,

2. An alternating sequence of sandstone and shale facies with sandstone comprising 15 to 50 percent of the sedimentary volume, and

3. A massive shale facies in which sandstone constitutes no more than 15 percent of the sediments.

Fluid pressures higher than normal (geopressures) are most commonly assoctated with the alternating sandstone and shale facies, and with the massive shale factes[1]. Thus, the sandstone reservoirs having greatest potential for development are likely to occur within the alternating sandstone and shale facies. Although the shales which contain the bulk of the accessible fluid resource have too low permeabilities to allow their direct development for fluid production, it has been suggested [1] that the shales may yield significant quantities of water to the permeable sandstone when subjected to production stress. The shales could thus act as sources of recharge for the sandstones and permit greater fluid recovery than that obtainable by pressure depletion of the sandstone reservoirs alone. 
The concept of shale recharge (i.e., water influx from the surrounding shale) was apparently first discussed by Wallace ${ }^{[2]}$. Wallace was mainly concerned with the production of gas from geopressured reservoirs along the Gulf coast. These reservoirs typically contain many thick sections of undercompacted shales with interspersed sand lenses. When pressures with in the sand lenses are reduced by gas production, the compaction process (of the shales) is allowed to resume, and water is expelled from the shales into the sands. According to Wallace, the shale water influx is governed by (1) the permeability and compressibility of the shale, (2) the pressure differential across the shale/sandstone interface, and (3) the contact area of the sand/shale interface. For geopressured geothermal reservoirs, Garg, et a1 [3] and Pritchett, et a1. [4] present some preliminary theoretical calculations on the effects of shale permeability and compressibility and shale/sand arrangement (i.e., sand/shale thickness) on shale water influx. The latter authors conclude that for vertical shale permeabilities of the order of $10^{-5} \mathrm{md}$, significant shale influx would occur only for production times longer than two to three years. Also shale water influx declines with a decrease in shale compressibility and an increase in sand thickness. Garg, et al. [3] note that the effects of shale compressibility will become evident only for long production times.

One of the main difficulties in assessing the importance of shale water influx in geopressured geothermal reservoirs is the current paucity of data on the relevant shale properties. Seevers[5] applied Nuclear Magnetic Resonance technique to calculate shale permeabilities from chips collected from a Gulf Coast well. The shale permeability ranges from a low of approximately $10^{-5} \mathrm{md}$ in the normally pressured region to a high of $4 \times 10^{-5}$ ind in the geopressured region. The latter values 
have, however, not been confirmed with direct measurements of permeability on shales[5]. Bredehoeft and Hanshaw [6] presented a hydrodynamic compaction model which possibly describes the creation of geopressured reservoirs; the results of this model imply that geopressures will exist if permeability is $10^{-2} \mathrm{md}$ or lower. The value of $10^{-2} \mathrm{md}$ is thus an upper limit on vertical shale permeability, and is apparently much larger than the permeability required for significant shale water influx due to production stress (see below). It is also appropriate to mention here the U. S. Department of Energy sponsored ongoing work on the laboratory determination of shale properties at the University of Texas at Austin (UTA). Preliminary UTA data suggest that the shale compresstbility is of the order of $10^{-6} \mathrm{psi}^{-1}[7]$.

The purpose of the present study is to determine the conditions under which significant shale recharge may be expected. We employ the reservoir simulator MUSHRM in its axisymmetric configuration to examine the effects of shale compressibility and vertical permeability on shale recharge. MUSHRM calculations yield the amount of fluids (brine and/or methane) produced, and also the bottom-hole production well pressures. Shale recharge helps to maintain the pore pressure in the sandstones, and thus allows greater fluid production. The present calculations suggest that shale recharge is a strong function of the vertical shale permeabilty but is not greatly influenced by the shale compressibility. For significant shale recharge to occur, the vertical shale permeability must be at least of the order of 0.01 „darcies. 


\section{NUMERICAL CALCULATIONS}

We consider a representative hypothetical bounded (no mass or energy flux across the boundaries) geopressured snadstone/shale reservoir. The reservoir is assumed to be a right circular cylinder with radius $R=5957.842 \mathrm{ft}$. (corresponding to a block area of $4 \mathrm{sq}$. miles) and height $h=260 \mathrm{ft}$. The net sand thickness of $60 \mathrm{ft}$. The numerical grid, along with the shale/sand arrangement, used is shown in Figure 1. Rock properties employed in the numerical calculations discussed below are given in Tables 1 and 2. The instantaneous porosity $(\phi)$ and permeability $\left(k_{v}\right.$ or $\left.k_{h}\right)$ are given by the following relations:

$$
\begin{aligned}
& \frac{\partial \phi}{\partial t}=(1-\phi) c_{m} \partial p / \partial t \\
& k=k_{0} \exp \left\{\frac{\phi-\phi_{0}}{\left(1-\phi_{0}\right)(1-\phi)}\right\}
\end{aligned}
$$

where

$$
\begin{aligned}
& p=\text { fluid pressure, } \\
& t=\text { time. }
\end{aligned}
$$

The reservoir fluid is assumed to be a brine (salinity by mass $S=$ 0.12 corresponding to a TOS of $130,000 \mathrm{ppm})$ saturated with methane. The initial pore pressure, temperature and methane mass fraction at a depth of $14,670 \mathrm{ft}$. are $P=11,503 \mathrm{psi}(-793$ bars $), T=280.4^{\circ} \mathrm{F}$ ( $=138^{\circ} \mathrm{C}$ ), and $\mathrm{C}=0.002706$. Initially, the reservoir fluids are assumed to be in hydrostatic equilibrium; the initial conditions assigned by the simulator are listed in Table 3 . The total pore volume, brine in pores, and gas in place are given in Table 4. The amount of methane dissolved in brine at the resevoir conditions is approximately 24.4 SCF/STB. 


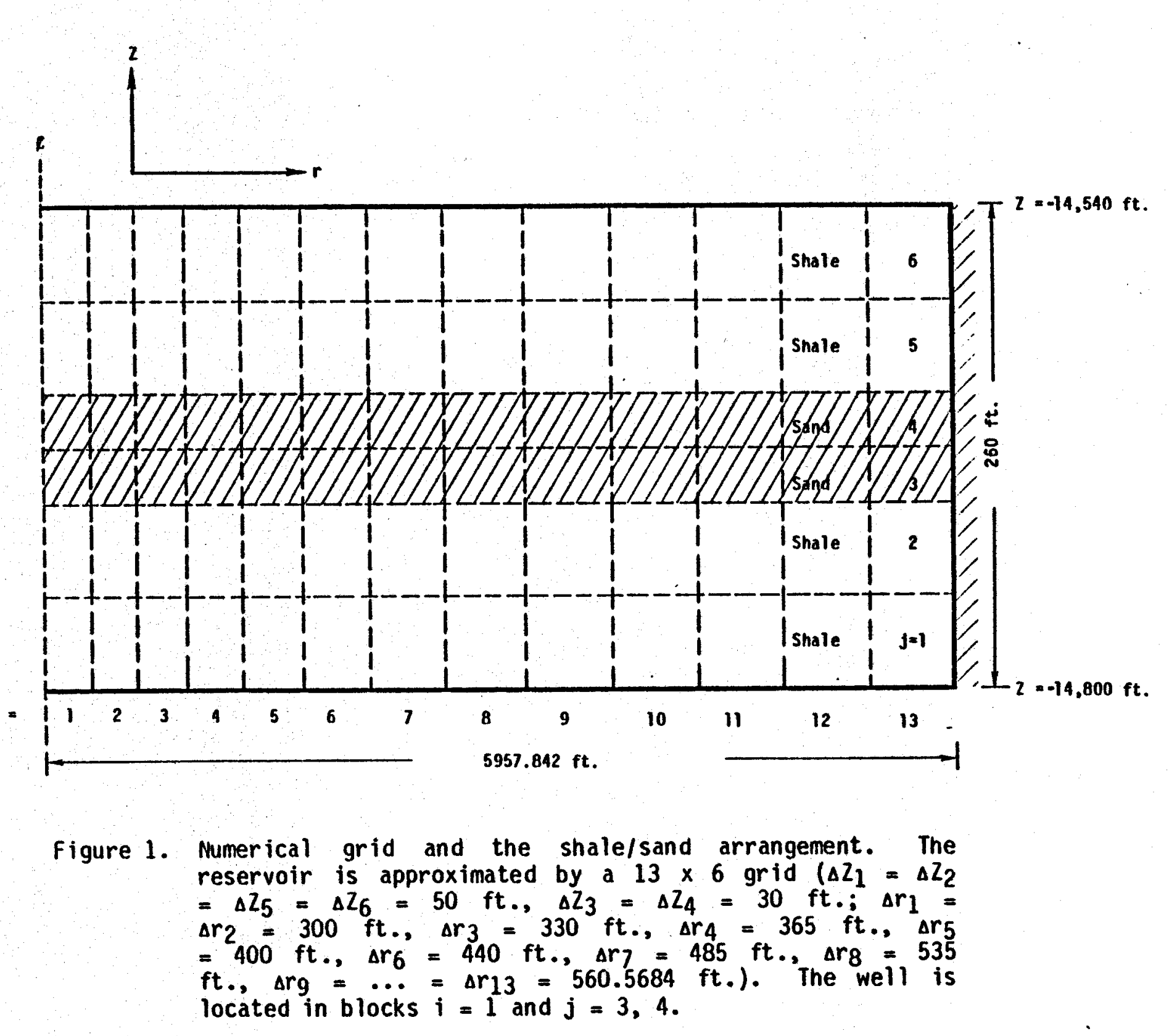


TABLE 1

ROCK PROPERTIES

Sandstone

Initial Porosity $\left(\phi_{0}\right)$

0.2

Grain Density (os)

Rock Grain Specific Heat ( $C_{V s}$ )

Rock Grain Thermal

Conductivity (Ks)

Initial Vertical

Permeability ( vo)

Initial Horizontal

Permeability ( ko)

Uniaxial Compressibility $\left(C_{m}\right)$
$164.41 \mathrm{bm} / \mathrm{ft}^{3}$

$\left(2.633 \mathrm{gm} / \mathrm{cm}^{3}\right)$

$0.23 \mathrm{Btu} / \mathrm{bm}^{\circ} \mathrm{F}$

$\left(0.963 \times 10^{7} \mathrm{ergs} / \mathrm{gm}^{\circ} \mathrm{C}\right)$

$3.03 \mathrm{Btu} / \mathrm{hr} \mathrm{ft}^{\circ} \mathrm{F}$

$\left(5.25 \times 10^{5} \mathrm{ergs} / \mathrm{sec} \mathrm{cm}^{\circ} \mathrm{C}\right)$

$\left(2 \times 10^{-11} \mathrm{~cm}^{2}\right)$

$\left(2 \times 10^{-10} \mathrm{~cm}^{2}\right)$

$10^{-6} \mathrm{psi}^{-1}$

(0.145 x $10^{-10} \mathrm{~cm}^{2} /$ dynes)
Shale

0.2

$164.41 \mathrm{bm} / \mathrm{ft}^{3}$

$\left(2.633 \mathrm{gm} / \mathrm{cm}^{3}\right)$

$0.23 \mathrm{Btu} / 1 \mathrm{bm} \mathrm{F}^{\circ} \mathrm{F}$

$\left(0.963 \times 10^{7} \mathrm{ergs} / \mathrm{gm}^{\circ} \mathrm{C}\right)$

3.03 Btu/hr ft ${ }^{\circ} \mathrm{F}$

$\left(5.25 \times 10^{5} \mathrm{ergs} / \mathrm{sec} \mathrm{cm}^{\circ} \mathrm{C}\right)$

see below

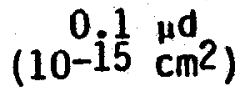

see below 


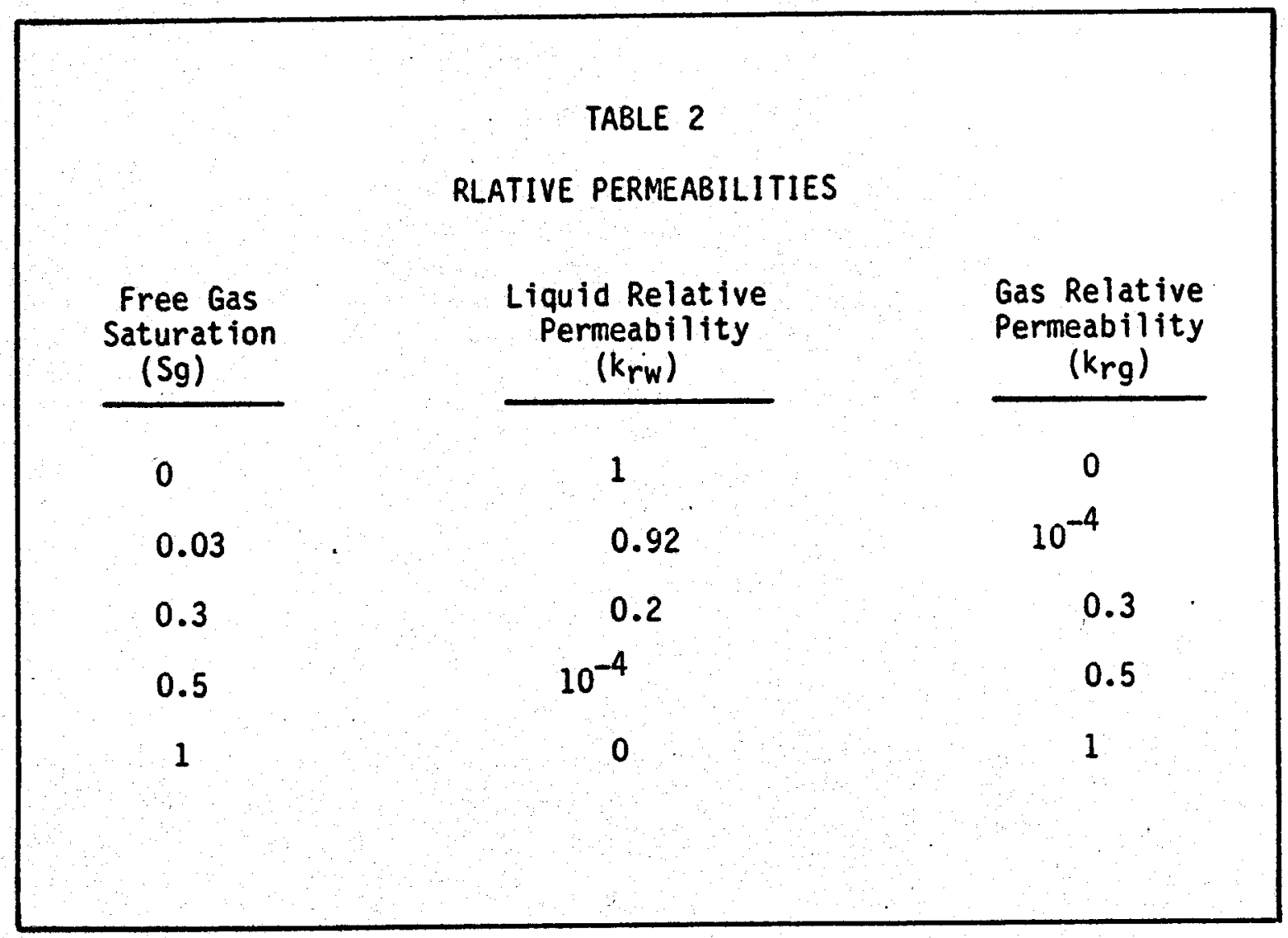


TABLE 3

INITIAL CONOITIONS ASSIGNED BY THE SIMULATOR

\begin{tabular}{|c|c|c|c|}
\hline \multicolumn{4}{|c|}{ TABLE 3} \\
\hline \multicolumn{4}{|c|}{ INITIAL CONOITIONS ASSIGNED BY THE SIMULATOR } \\
\hline j & Rock Type & Pressure & $\begin{array}{l}\text { Methane Mass } \\
\text { Fractions } \\
\end{array}$ \\
\hline 1 & Shale & $\begin{array}{c}11,550 \text { psi } \\
(796.4 \text { bars })\end{array}$ & 0.002713 \\
\hline 2 & Shale & $\begin{array}{c}11,527 \text { psi } \\
(794.8 \text { bars })\end{array}$ & 0.002710 \\
\hline 3 & Sand & $\begin{array}{c}11,509 \text { psi } \\
(793.5 \text { bars })\end{array}$ & 0.002707 \\
\hline 4 & Sand & $\begin{array}{c}11,496 \text { psi } \\
(792.6 \text { bars })\end{array}$ & 0.002705 \\
\hline 5 & Shale & $\begin{array}{c}11,478 \text { psi } \\
\text { (791.3 bars) }\end{array}$ & 0.002703 \\
\hline 6 & Shale & $\begin{array}{c}11,455 \text { psi } \\
\text { (789.8 bars) }\end{array}$ & 0.002699 \\
\hline
\end{tabular}




\section{TABLE 4}

PORE VOLUME, BRINE IN PORES, AND GAS IN PLACE

Rock Type Pore Volume Brine Gas

$\begin{array}{lllll}\text { Shale } & 4.46 \times 10^{9} \mathrm{ft}^{3} & 7.64 \times 10^{8} \mathrm{STB}^{*} & 1.864 \times 1010 \mathrm{SCF} * \star \\ & \left(1.263 \times 10^{8} \mathrm{~m}^{3}\right) & \left(1.319 \times 10^{11} \mathrm{~kg}\right) & \left(3.58 \times 10^{8} \mathrm{~kg}\right) \\ \text { Sand } & 1.338 \times 10^{9} \mathrm{ft}^{3} & 2.29 \times 10^{8} \mathrm{STB}^{*} & 5.59 \times 10^{9} \mathrm{SCF} \mathrm{SH}^{*} \\ & \left(3.79 \times 10^{7} \mathrm{~m}^{3}\right) & \left(3.96 \times 10^{2} \mathrm{~kg}\right) & \left(1.074 \times 10^{8} \mathrm{~kg}\right)\end{array}$

* $\quad 1$ STB $=1 \mathrm{bbl}$ of brine at standard conditions $\left(P=14.5 \mathrm{psi}, T=60^{\circ} \mathrm{F}\right)$. Specific volume of brine $(S=0.12)$ at standard conditions is $5.788614 \times$ 10-3 STB $/ \mathrm{kg}$.

$\star \star 1 S C F=1 \mathrm{ft}^{3}$ of methane at standard conditions $(P=14.5 \mathrm{psi}, T=$ $60^{\circ} \mathrm{F}$ ). Specific volume of methane at standard conditions is $52.06 \mathrm{SCF} / \mathrm{kg}$. 
The reservoir is produced by a single $5.5 \mathrm{in} .(=13.97 \mathrm{~cm})$ diameter well located at the center of the reservoir (in Zones $i=$ $1, J=3,4)$ at a constant rate of 10,000 STB $10(-20 \mathrm{~kg} / \mathrm{s})$ until the bottom hole pressure (datum $Z=-14,640$ bars) falls to 6670 psi ( 460 bars); thereafter the BHP is maintained at 6670 psi and the fluid production is allowed to decline.* The calculations were terminated if either the production rate fell below 2000 STB/D $(-4$ $\mathrm{kg} / \mathrm{s}$ ) or the production time exceeded 6 years.

In the absence of any shale recharge, the amount of fluid (expressed as a fraction of the fluid initially present in the sands) producible by primary pressure depletion of the reservoir sands is given by $C_{T}$ sand $\left(P_{i}-P_{h}-P_{f}\right)$ where $P_{i}$ is the initial reservoir pressure, and

$$
\begin{aligned}
& c_{T, \text { sand }}=\left(\frac{1-\phi}{\phi}\right) c_{m \text { sand }}+c_{f} \\
& c_{f}=\text { Fluid (water/methane) mixture compressibility }
\end{aligned}
$$

Assuming an initial reservoir pressure $P_{1}$ of 11,490 psi (pressure at the top of the sand layer), an average $\left(P_{h}+P_{f}\right)-6670 \mathrm{psi}$, $0-0.2, c_{m}$, sand $-10^{-6} p s^{-1}$ and $c_{f}-3.35 \times 10^{-6}$ psi-1, the fraction of fluid recoverable by pressure depletion of sands is approximately 3.54 percent. The latter figure is an upper limit since declining flow rate will cause abandonment of the wells before the production rate reaches zero.

The well will flow only if the bottom-hole pressure is maintained above $\left(P_{h}+P_{f}\right)\left(P_{h}=\right.$ hydrostatic pressure, $P_{f}=$ frictional pressure loss in the tubing). The hydrostatic pressure, based on the fluid density in situ is approximately 6640 psi ( -458 bars). It is assumed here that two-phase flow occurs in the wellbore and sufficient gas percolates through the liquid column to reduce $P_{h}$ such that $\left(P_{h}+P_{f}\right)<6670$ psi ( 460 bars). 
A series of six cases was considered to assess the sensitivity of shale recharge (and its effect on the production behavior of the well) to variations in vertical shale permeability (Cases 1-4), and uniaxial shale compressibility (Cases 5 and 6 ). The values of the latter parameters (i.e., $k_{v o}$ and $C_{m}$ for shale) for the various Cases are listed in Table 5. Figure 2 gives the bottom-hole pressure for Cases 1-4. The bottom-hole pressure, in Cases 1-3, drops to 6670 psi in approximately 0.80 years; in Case 4 / $k_{\text {vo }}=$ $0.1 \mathrm{ud}$ ), the bottom-hole pressure stays above 6670 psi for slightly more than 0.95 years. The instantaneous brine production rate for Cases $1-4$ is shown in Figure 3 . In Cases 1 and 2 , the brine production rate drops below 2,000 STB/D in 3.2 years. For $k_{v o}=$ 0.01 id (Case 3 ), the brine production rate can be maintained above 2,000 STB/0 for more than 4.4 years. The most dramatic improvement in brine production rate is seen for case 4 ; in this instance, the brine production stays above 6500 STB/D for the duration of the calculation ( $=6$ years). Flnally, the cumulative methane production is shown in Figure 4. The cumulative methane production for Cases 1 and 2 is virtually identical; the total methane production for case 3 is 18 percent more than that for cases 1 and 2. For case 4 , the cumulative methane production $(t=6$ years) is more than twice that obtained for cases 1 and 2. The results of these calculations clearly indicate that for shale recharge to be effective, vertical shale permeability needs to be at least of the order of $0.01 \mu \mathrm{d}$. If vertical shale permeability is of $0(0.001 \mu d)$, little or no shale recharge will occur for practical production times.

Table 6 summarizes the brine and methane production data for all the six cases. Cases 5 and 6 (identical with cases 3 and 4 except for shale compressibility) were designed to assess the effect of shale compressibility on reservoir production behavior. A comparison of Cases 3 and 4 with Cases 5 and 6 (Table 6) clearly shows that even a ten-fold increase in shale compressibility has no significant impact on reservoir production behavior. 
TABLE 5

VERTICAL SHALE PERMEABILITY (kvo) AND UNIAXIAL SHALE COMPRESSIBILITY $\left(\mathrm{C}_{\mathrm{m}}\right)$

Vertical Shale Permeability (kvo)

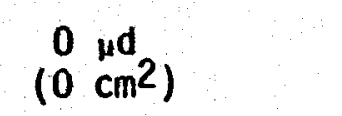

$0.001 \mu \mathrm{d}$ $\left(10^{-17} \mathrm{~cm}^{2}\right)$

$\left(10^{-16^{\mu d}} \mathrm{~cm}^{2}\right)$

4

5

6 $\left(10^{-1} 5^{\mu d} \mathrm{~cm}^{2}\right)$

$\left.\stackrel{0.01}{\left(10^{-1} 6^{\mu d}\right.} \mathrm{cm}^{2}\right)$

$\stackrel{0.1}{\left(10^{-1} 5^{\mathrm{d}} \mathrm{cm}^{2}\right)}$
Uniaxial Shale Compressibility

$$
10^{-5} \mathrm{psi}-1
$$

(0.145 $\times 10^{-9} \mathrm{~cm}^{2} /$ dynes)

10-5 psi-1

(0.145 $\times 10^{-9} \mathrm{~cm}^{2} /$ dynes)

10-5 psi-1

(0.145 $\times 10^{-9} \mathrm{~cm}^{2} /$ dynes)

10-5 psi-1

(0.145 x 10-9 $\mathrm{cm}^{2} /$ dynes)

10-4 psi-1

(0.145 $\times 10^{-8} \mathrm{~cm}^{2}$ /dynes)

10-4 psi-1

(0.145 x 10-8 $\mathrm{cm}^{2} /$ dynes) 


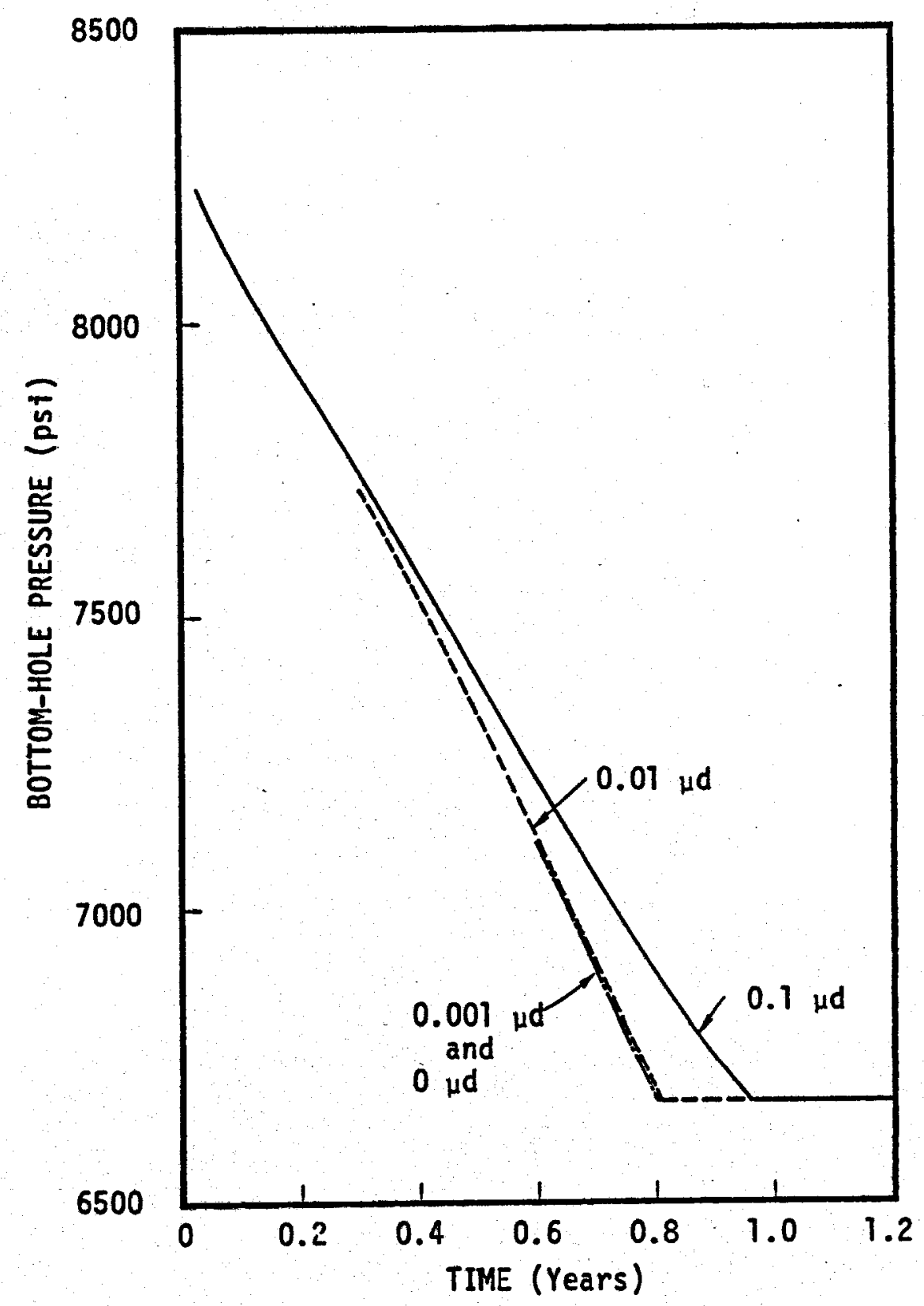

Figure 2. Effect of vertical shale permeability on bottom-hole pressure. 


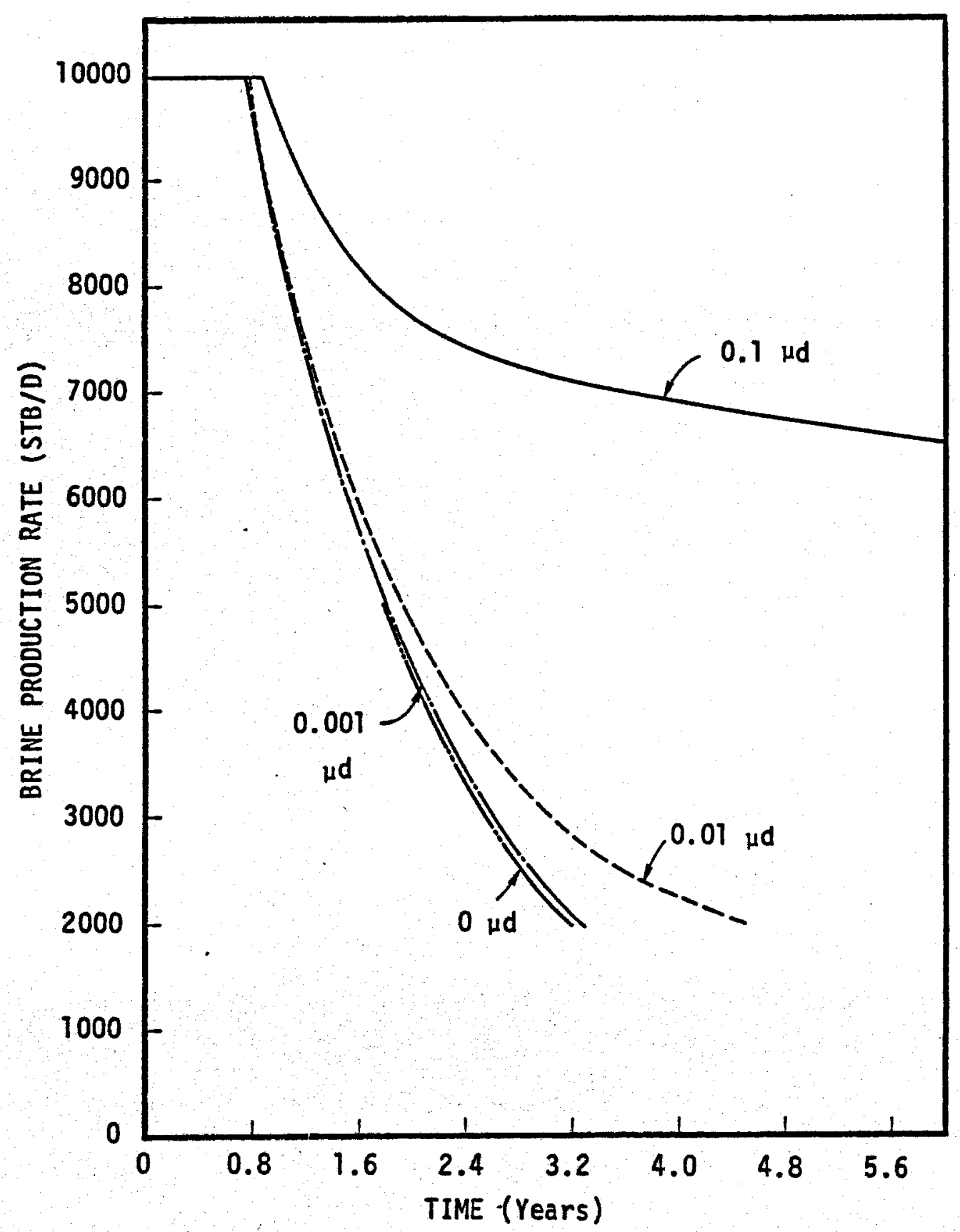

Figure 3. Effect of vertical shale permeability on the instantaneous brine production rate. 


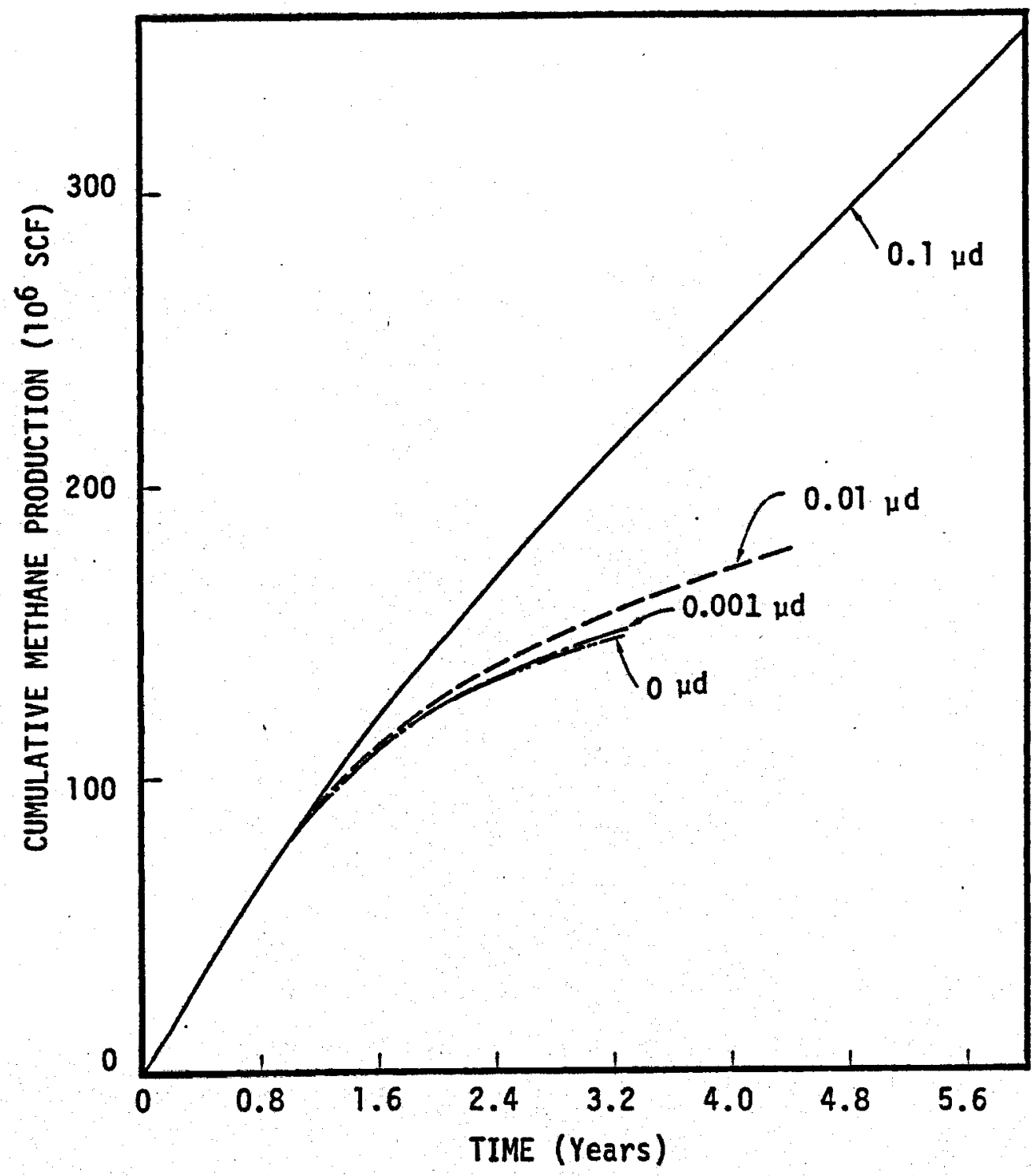

Figure 4. Effect of vertical shale permeability on cumulative methane production. 
TABLE 6

SUMMARY OF BRINE ANO METHANE PRODUCTION

Percentages denote fraction of the brine (methane) in place in sand alone.

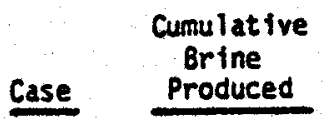

$1 \quad 7.06 \times 106 \mathrm{STB}$

$-1.22 \times 10^{9} \mathrm{~kg}$ (3.088)

$27.19 \times 106 \mathrm{STB}$

$-1.24 \times 10^{9} \mathrm{~kg}$ (3.148)

$3 \quad 8.59 \times 1065 T 8$

$-1.48 \times 10^{9} \mathrm{~kg}$ (3.75\%)

$4 \quad 1.69 \times 10^{7} \mathrm{STB}$

$-2.91 \times 10^{9} \mathrm{~kg}$ (7.36\%)

$5 \quad 8.60 \times 106 \mathrm{STB}$

$-1.49 \times 10^{9} \mathrm{~kg}$ (3.758)

$6 \quad 1.76 \times 10^{7}$ STB

$-3.03 \times 10^{9} \mathrm{~kg}$ (7.668)

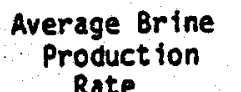

Rate

6,040 STB 10

for 3.2 years

5,970 STB $/ 0$

for 3.3 years

5,230 STB $/ 0$

for 4.5 years

$7,700 \mathrm{STB} / \mathrm{O}$

for 6 years

5,240 STB 10

for 4.5 years

$8,0205 T 8 / 0$

for 6 years

\section{Cumulat ive \\ Methane \\ Produced}

$1.49 \times 108 \mathrm{SCF}$

$-2.86 \times 10^{6} \mathrm{~kg}$ (2.668)

$1.51 \times 108 \mathrm{SCF}$

$-2.91 \times 106 \mathrm{~kg}$ (2.718)

$1.78 \times 108 \mathrm{SCF}$

$-3.43 \times 106 \mathrm{~kg}$ $(3.198)$

$3.55 \times 108$ SCF

$-6.81 \times 106 \mathrm{~kg}$

(6.348)

$1.79 \times 108$ SCF

$-3.43 \times 106 \mathrm{~kg}$

(3.208)

$3.71 \times 10^{8} \mathrm{SCF}$

$-7.12 \times 10^{6} \mathrm{~kg}$ (6.638)
Average Methane Content of Produced fluid

21.1 SCF/STB

21.1 SCF/STB

20.8 SCF/STB

21.0 SCF/STB

20.8 SCF/STB

21.1 SCF/STB 


\section{iII. SUMMARY AND CONCLUSIONS}

The calculations presented in the preceding section imply that shale recharge strongly depends upon the vertical shale permeablitity, but is largely unaffected by the uniaxial shale compressibility. For practical production times, significant shale recharge will take place only if the vertical shale permeability is at least of $0(0.01 \mu d)$. Although present indications are that vertical shale permeabilities of the order of $0.01 \mu d$ are reasonable for geopressured reservoirs, it must be stressed that no direct measurement of shale permeability are currently available. To evaluate the possibility of shale recharge in geopressured reservoirs, it is clearly necessary to obtain reliable estimates of in situ shale permeabilities. 


\section{REFERENCES}

1. Wallace, R. H., Jr., Kraemer, T. F., Taylor, R. E. and Wesselman, J. B., "Assessment of Geopressured - Geothermal Resources in the Northern Gulf of Mexico Basin," in Assessment of Geothermal Resources of the United States-1978, (L. J. P. Muffler, Editor), Circular 790, United States Geological Survey, 1979, pp. 132-155.

2. Wallace, W. E., "Water Production from Abnormally pressured Gas Reservoirs in South Louisiana, Part II," Society of Petroleum Engineers Preprint No. SPE 2225, 1968.

3. Garg, S. K., Pritchett, J. W., Brownell, O. H., Jr., and Riney, T. D., "Geopressured Geothermal Reservoir and Wellbore Simulation," Systems, Science and Software, La Jolla, CA, Report SSS-R-78-3639, 1978.

4. Pritchett, J. W., Garg, S. K., Rice, M. H., and Riney, T. O., "Geopressured Reservoir Simulation," Systems, Science and Software, La Jolla, CA, Report SSS-R-79-4022, 1979.

5. Seevers, 0. 0., "A Method of Determining Permeability by Means of a Pulsed NMR and an Application of the Method to the Study of a Gulf Coast Supernormally Pressured Well," Society of Petroleum Engineers Preprint No. SPE 3847, 1972.

6. Bredehoeft, J. D. and Hanshaw, B. B., "On the Maintenance of Anomalous Fluid Pressures: 1. Thick Sedimentary Sequences," Geological Society America Bulletin, Vol. 79, pp. 1097-1106, 1968.

7. MacDonald, R. C., personal communication, 1979. 